\title{
Curvas de lactancia individuales en vacas Siboney de Cuba
}

\section{Individual lactation curves in Siboney dairy cows of Cuba}

\author{
Alejandro Palacios Espinosaa, Dianelys González-Peña Fundorab, Danilo Guerra Iglesiasc, \\ José Luis Espinoza Villavicencioa, Ricardo Ortega Péreza, Ariel Guillén Trujilloa, \\ Narciso Ávila Serranod
}

\begin{abstract}
RESUMEN
El objetivo fue estudiar y modelar las curvas de lactancia individuales en vacas Siboney, comparando cuatro modelos matemáticos. En total, 31,631 registros de producción de leche del día de control (PDC) de 3,697 lactancias (1 a 5) provenientes de 2,632 vacas Siboney de Cuba (5/8 Holstein 3/8 Cebú Cubano) registrados mensualmente entre 1994 y 2003 se ajustaron mediante las funciones de Wood, Wilmink, Ali-Schaeffer y Polinomios de Legendre. Los parámetros se estimaron usando regresiones no lineales y la bondad de ajuste se midió mediante el coeficiente de determinación ajustado $\left(R^{2} A\right)$. Se obtuvieron valores de $R^{2}$ A 0.75 en 23, 24, 28 y $36 \%$ de las lactancias para los modelos de Wood, Wilmink, Ali-Schaeffer y Polinomios de Legendre, respectivamente. Los modelos de Wood y Wilmink describieron cuatro tipos de curvas; y los modelos de Ali-Schaeffer y los Polinomios de Legendre 17 y 20, de los 32 grupos teóricos posibles. Las correlaciones entre los parámetros para la función de Ali-Schaeffer fueron superiores a las estimadas para los polinomios de Legendre. Las funciones propuestas representaron las diferentes formas entre curvas de lactancia y en especial, los modelos de cinco parámetros detectaron mayor diversidad que el resto de las funciones. Esto apunta que, aunque formas adicionales pueden considerarse como derivaciones de los dos grupos clásicos de curvas típicas o atípicas, esta práctica podría comprometer la variabilidad entre curvas de lactancia en un hato, por lo que serán necesarios más estudios.
\end{abstract}

PALABRAS CLAVE: Vacas, Lactancia, Curvas, Modelos matemáticos.

\begin{abstract}
The objective was to study and to model the individual lactation curves in Siboney cows comparing four mathematical models. In total, 31,631 test day milk production records (TD) of 3,697 lactations (1 to 5) from 2,632 Siboney cows of Cuba (5/8 Holstein, 3/8 Cebu Cuban) monthly recorded between 1994 and 2003 were adjusted using the functions of Wood, Wilmink, Ali-Schaeffer and Legendre polynomials. The parameters were estimated using nonlinear regressions and the goodness of fit was measured by the adjusted coefficient of determination $\left(R^{2} A\right)$. Values of $R^{2}>0.75$ in $23,24,28$, and $36 \%$ of the lactations for the models of Wood, Wilmink, Ali-Schaeffer and Legendre polynomials, respectively, were obtained. The models of Wood and Wilmink described four types of curves and the models of Ali-Schaeffer and the Legendre polynomials 17 and 20 for 32 possible theoretical groups. The correlations among the parameters of Ali-Schaeffer function were higher than that estimated for the Legendre polynomials. The proposed functions represented the different shapes among lactation curves and in particular the five parameters models detected higher diversity related to the rest of the function. This pointed that even if additional detected shapes can be considered as derivations of the two classical groups of typical or atypical curves, this practice could compromise the variability among lactation curves inside a herd, therefore further studies are needed.
\end{abstract}

KEY WORDS: Cows, Lactation curves, Mathematical models.

Recibido el 23 de octubre de 2014. Aceptado el 24 de noviembre de 2014.

a Universidad Autónoma de Baja California Sur, México. Carr. al Sur, km. 5.5, La Paz, B.C.S. CP 23080. México. jlvilla@uabcs.mx. Correspondencia al cuarto autor.

b Universidad de Illinois, USA.

c Centro de Investigación para el Mejoramiento Animal de la Ganadería Tropical, La Habana, Cuba.

d Universidad del Mar, Puerto Escondido, Oaxaca, México. 


\section{INTRODUCCIÓN}

La curva de lactancia puede ser definida como un proceso biológico explicado por una ecuación matemática(1), la cual es útil en el pronóstico de la producción total a partir de muestras parciales. La cantidad de leche producida depende de la trayectoria de la curva de lactancia, la cual es influenciada por factores genéticos y ambientales(2). La curva de lactancia es una herramienta que permite entender $y$ evaluar el comportamiento fisiológico de la producción de leche y puede usarse para conocer el potencial genético de un hato o raza de ganado lechero(3). El conocimiento de las curvas de lactancia permite predecir la producción total de leche con una o varias mediciones realizadas los días de control en lactancias tempranas(4). El potencial genético para la producción de leche, así como la forma y altura de la curva son influenciadas por lactancias consecutivas, edad al parto, la estación en que ocurre el parto(5), etapa de la preñez(6) y por la longitud del periodo seco previo(2). Además, los sistemas de manejo y alimentación diferentes en las distintas zonas geográficas, regiones y países influyen de manera importante en la producción de las vacas lecheras $(7,8,9)$.

Se han usado varios modelos matemáticos para describir las curvas de lactancia y estimar la producción de leche esperada(2). Algunos están orientados a un mejor ajuste de las funciones matemáticas con una menor consideración de la biología de la lactación(10) y otros están enfocados a mejorar el entendimiento de los procesos biológicos(11).

Cuando se ajustan las producciones del día de control con ecuaciones de regresión empíricas pueden detectarse varias formas de curvas de lactancia; algunas de ellas consisten en ligeras modificaciones de la curva estándar, por ejemplo, por la presencia o ausencia de un punto de inflexión en la parte decreciente de la lactancia; otras son diferentes, como las curvas que decrecen continuamente y carecen del pico de lactancia(12).

\section{INTRODUCTION}

A lactation curve is the result of an explanation of a biological process with a mathematical function(1), and is useful in predicting total production from partial samples. Milk production is represented by the lactation curve trajectory, and is influenced by genetic and environmental factors $(2)$. Lactation curves help to understand milk production physiological behavior and can be used to research the genetic potential of a dairy cattle herd or breed(3). By applying lactation curves, total milk production can be predicted with one or a number of measurements taken on control days in early lactations(4). Milk production genetic potential and the shape and height of lactation curves are affected by factors such as the number of consecutive lactations, age at parturition, season of calving(5), gestation stage(6), and length of previous dry period(2). The handling and feed systems used in different geographic zones, regions and countries can also have a significant effect on dairy cow milk production $(7,8,9)$.

Many mathematical models have been used to describe lactation and estimate expected milk production(2). Some of these models focus on attaining the best fit for the mathematical equations and give less weight to lactation biology $(10)$, while others aim at improving understanding of biological processes(11).

When control day production data are fitted using empirical regression equations, different lactation curve shapes can be identified. Some are slight modifications of the standard (typical) curve, for instance, due to the presence or absence of inflection points in the descending portion of a lactation curve. Others can differ notably from the standard curve, such as curves that decline continually and have no lactation peak(12).

Most studies using lactation curves are focused on identifying the curve with the best fit among average curves. That with the best fit is then used to fit all the lactations in a data set. Applying these criteria to identify the best model 
En general, los estudios se han dirigido a curvas promedio para seleccionar aquélla con mejor ajuste, y esta función es adoptada para el ajuste de todas las lactancias en el conjunto de datos. Estos criterios para seleccionar el mejor modelo muchas veces ignoran los problemas estadísticos o biológicos que pueden ocurrir cuando el ajuste es extendido a lactancias individuales. Las consecuencias pueden ser estimaciones de parámetros irreales(13).

El concepto primario de los modelos genéticos para producción de leche se basa en que los animales pueden diferir genéticamente, no solo en la producción de leche total, sino también en la forma de la curva de lactancia(14). Esta variación en la forma de la curva individual de producción de leche se ha investigado en varias especies $(5,15)$. Sin embargo, es importante encontrar para cada circunstancia de producción, la función matemática que mejor describa el fenómeno en cuestión(16). El objetivo de este trabajo fue estudiar y modelar, a partir de cuatro modelos matemáticos, las curvas de lactancia individuales que se presentan en el genotipo Siboney de Cuba.

\section{MATERIAL Y MÉTODOS}

Se utilizó información de ganado bovino Siboney (5/8 Holstein 3/8 Cebú Cubano) de la provincia Pinar del Río, Cuba. En dicha región existen dos estaciones claramente definidas, la de lluvias (verano) de mayo a octubre, con 70 a $80 \%$ de la precipitación $(960 \mathrm{~mm})$, y la estación seca (invierno) de noviembre a abril $(240 \mathrm{~mm})$. La temperatura media anual es de $23.1{ }^{\circ} \mathrm{C}$, con humedad relativa de 60 a $70 \%$ durante el día y de 80 a $90 \%$ durante la noche(17).

Se analizaron 31,631 registros de producción de leche del día de control (PDC) de 3,697 lactancias (de la primera a la quinta) controladas mensualmente en 2,632 vacas nacidas entre 1987 y 1999. El sistema de alimentación estuvo basado en pastoreo de $12 \mathrm{~h}$ al día, aproximadamente. Los pastos utilizados fueron zacate estrella (Cynodon nlemfuensis) y Guinea often ignores statistical or biological problems that may occur when the fit is extended to individual lactations. This can result in inaccurate parameter estimation(13).

In milk production genetic models, the primary concept is that animals can differ genetically, both in terms of total milk production and their lactation curve shape(14). Variation in milk production curve shape occurs in different species $(5,15)$. Given this variation, it is vital to find the most appropriate mathematical function that best describes each production situation(16).

The present study objective was to apply four mathematical models to analyze and model individual lactation curves in the Siboney genotype of Cuba.

\section{MATERIAL AND METHODS}

Data analyzed in this study were from Siboney cattle (5/8 Holstein, 3/8 Cuban Zebu) from Pinar del Río province, Cuba. This region has two clearly defined seasons: a rainy season from May to October with 70 to $80 \%(960 \mathrm{~mm})$ of yearly rainfall; and a dry season from November to April $(240 \mathrm{~mm})$. Average annual temperature is $23.1{ }^{\circ} \mathrm{C}$, relative daytime humidity is 60 to $70 \%$ and relative nighttime humidity is 80 to $90 \%(17)$.

A total of 31,631 test day milk yield (TDMY) records were analyzed from 3,697 monthly controlled lactations (first to fifth) in 2,632 cows born between 1987 and 1999. Feed system was daily grazing for approximately $12 \mathrm{~h}$ daily. Star grass and Guinea grass were the principal feed, although the cows also grazed naturally occurring grasses in the rainy season. The cows were milked twice daily, and provided a 0.45 $\mathrm{kg}$ concentrate supplement beginning at the fourth liter of milk produced. The cows were corralled at night and fed king grass (Penisetum purpureum) and sugar cane (Saccharum officinarum). 
(Panicum maximum), y durante la estación de lluvias las vacas consumieron también pastos naturales. Las vacas se ordeñaron dos veces al día y durante cada ordeño se suplementaron con $0.45 \mathrm{~kg}$ de concentrado a partir del cuarto litro de leche producido. Por las noches, los animales se confinaron y se alimentaron con king grass (Penisetum purpureum) y caña de azúcar (Saccharum officinarum).

Para modelar curvas de lactancia se utilizaron las siguientes funciones previamente aplicadas y usadas en la población para modelar curvas promedios:

$\operatorname{Wood}(10): Y_{t}=a \cdot t^{b} \cdot e^{c t}$

Wilmink(18): $Y_{t}=a+b e^{-k t+c t}$

Ali y Schaeffer(19): $Y_{t}=a+b(t / 330)+c(t / 330)^{2+}$ $\operatorname{dlog}(330 / t)+k[\log (330 / t)]^{2}$

Polinomios de Legendre normalizados de cuarto orden(20): $Y_{t}=\propto_{0} X P_{0}+\propto_{1} X P_{1}+\propto_{2} X P_{2}+\propto_{3} X P_{3}$ $+\propto_{4} x P_{4}$

En todos los modelos, $Y_{t}$ es la PDC en el tiempo $t$, correspondiente a los días en lactancia al momento del pesaje de la leche. Los parámetros $a, b$, y $c$ se encuentran asociados al nivel de producción y el parámetro $\mathrm{k}$ está relacionado con el tiempo al pico de lactancia y usualmente se asume como fijo $(18,21)$. En el modelo de Wilmink se asumió que $\mathrm{k}=0.10(22)$. Las funciones de tiempo $P j$ de los modelos que utilizan polinomios de Legendre se calcularon con los valores publicados por Schaeffer(23).

\section{Clasificación de las curvas de lactancia}

En la función de Wood, cuando $b>0$ y $c<0$ corresponde a una curva estándar (típica). Por el contrario, si $b<0$ y $c>0$ se presenta una curva reversa con una fase inicial decreciente, seguida de un incremento. La combinación de $b>0$ y $c>0$ representa una curva que aumenta continuamente, mientras que la solución $b<0$ y $c<0$ describe una curva que decrece continuamente(24).
Lactation curves were modeled using four functions applied previously in this population to model average curves:

$\operatorname{Wood}(10): Y_{t}=a \cdot t^{b} \cdot e^{c t}$

Wilmink(18): $Y_{t}=a+b e^{-k t+c t}$

Ali and Schaeffer(19): $Y_{t}=a+b(t / 330)+c(t / 330)^{2+}$ $\operatorname{dlog}(330 / t)+k[\log (330 / t)]^{2}$

Fourth order, normalized Legendre orthogonal polynomials (20): $Y_{t}=\propto_{0} x P_{0}+\propto_{1} x P_{1}+\propto_{2} x P_{2}+\propto_{3} x P_{3}$ $+\propto_{4} x P_{4}$

In all four models, $Y_{t}$ is TDMY in time $\mathrm{t}$, corresponding to lactation days at the time of milk weighing. Parameters $\mathrm{a}, \mathrm{b}$, and $\mathrm{c}$ are associated with production level, and parameter $\mathrm{k}$ is linked to time at peak lactation and is usually assumed to be fixed(18,21). In the Wilmink model, $\mathrm{k}=0.10$ was assumed(22). Time functions $(P J)$ included in the models using Legendre polynomials were calculated with values published by Schaeffer(23).

\section{Lactation curve classification}

In the Wood function, $b>0$ and $c<0$ corresponded to a standard (typical) curve. In contrast, if $b<0$ and $c>0$, the curve was a reverse standard curve with an initially decreasing phase followed by an increase. The $b>0$ and $c>0$ combination represents $a$ continuously increasing curve, while $b<0$ and $c<0$ describes a continuously decreasing curve(24).

The same four curve shapes can be described by the Wilmink function but with different parameter values: $b<0$ and $c<0$ is a typical curve; $b>0$ and $c>0$ is a reverse curve with $a$ minimum point; $b<0$ and $c>0$ is a continuously increasing curve; and $b>0$ and $c<0$ corresponds to a continuously decreasing curve(15).

The Ali-Schaeffer and Legendre polynomials functions describe 32 possible lactation curve shapes (25). 
Las mismas cuatro formas de curva pueden ser descritas por la función de Wilmink pero con diferente valor de parámetros, ya que si $b<0$ y $c<0$ se presenta la forma típica de la curva, mientras que si $b>0$ y $c>0$ la curva es reversa con un punto mínimo. Valores de $b<0$ y $c>0$ resultan en una curva que se incrementa continuamente, mientras que $b>0$ y $c<0$ corresponde a una curva decreciente en forma continua(15).

Las funciones de Ali-Schaeffer y polinomios de Legendre describen 32 posibles formas de curvas de lactancia(25).

La bondad de ajuste de los cuatro modelos utilizados se determinó mediante el $\mathrm{R}^{2} \mathrm{~A}$ y fue clasificado en cuatro niveles $(1<0.24 ; 2=0.25$ $0.49 ; 3=0.50-0.74 ; 4>0.75$ ) con el objetivo de crear clases que permitieran observar el ajuste de los modelos a las diversas curvas de lactancia individuales.

Sólo se utilizaron las curvas individuales con $\mathrm{R}^{2} \mathrm{~A}$ superiores a 0.75 . Las curvas de lactancia se agruparon de acuerdo a la combinación de los valores de sus parámetros, calculándose la correlación entre los mismos. Los análisis se efectuaron con el procedimiento NLIN del SAS(26).

\section{RESULTADOS}

La producción promedio de leche del día de control fluctuó entre $5.9 \pm 3.3$ y $3.7 \pm 2.0 \mathrm{~kg}$ con una media general de $4.9 \pm 2.7 \mathrm{~kg}$ entre las PDC. El 23, 24, 28 y $36 \%$ de las lactancias presentaron $\mathrm{R}^{2} \mathrm{~A}$ superiores a 0.75 para las funciones de Wood, Wilmink, Ali-Schaeffer y polinomios de Legendre (Cuadro 1).

Al seleccionar las curvas con $\mathrm{R}^{2} \mathrm{~A}$ superiores a 0.75 , los modelos de tres parámetros reconocieron los cuatro tipos de curvas posibles (Cuadro 2). El modelo de Wood detectó un mayor número de curvas estándar $(61 \%)$ en comparación con el modelo de Wilmink (47\%).
Goodness of fit for all four models was calculated with $\mathrm{R}^{2} \mathrm{~A}$ and classified in four levels $(1<0.24$; $2=0.25-0.49 ; 3=0.50-0.74 ; 4>0.75)$. The resulting categories helped to observe model fit to the different individual lactation curves. Only individual curves with $\mathrm{R}^{2} \mathrm{~A}>0.75$ were used. The lactation curves were grouped based on the combination of the values of their parameters, and the correlation between them calculated. All analyses were run with the NLIN procedure in the SAS package(26).

\section{RESULTS}

Average TDMY varied from $5.9 \pm 3.3$ to $3.7 \pm$ $2.0 \mathrm{~kg}$, with an overall mean of $4.9 \pm 2.7 \mathrm{~kg}$. Values for $\mathrm{R}^{2} \mathrm{~A}$ were $>0.75$ in $23 \%$ of lactations using the Wood function, $24 \%$ using the Wilmink function, $28 \%$ with the Ali-Schaeffer function, and $36 \%$ when using the Legendre polynomials function (Table 1 ). When $\mathrm{R}^{2} \mathrm{~A}$ curves $>0.75$ were selected, the three-parameter models identified four types of curves (Table 2). The Wood model identified more (61 \%) standard curves than the Wilmink model (47\%).

In curves modeled with the Wood function for increasing $b$ values, estimates during the first lactation increased (Figure 1a), whereas in atypical curves increases in $b$ did not persist (Figure 1b). With the Wilmink function, in

Cuadro 1. Frecuencias absolutas y porcentajes relativos (en paréntesis) de los ajustes en diferentes clases de coeficientes de determinación ajustados $\left(R^{2} A\right)$

Table 1. Absolute frequencies and relative percentages (in parentheses) of fits in different classes of fitted coefficients of determination $\left(\mathrm{R}^{2} \mathrm{~A}\right)$

\begin{tabular}{lrrrr}
\hline & \multicolumn{4}{c}{ Models } \\
\cline { 2 - 5 } $\mathrm{R}^{2} \mathrm{~A}$ & \multicolumn{1}{c}{ Wood } & \multicolumn{1}{c}{ Wilmink } & Ali-Schaeffer & Legendre \\
\hline$<0.25$ & $1677(45.3)$ & $1560(42.2)$ & $1367(36.9)$ & $824(22.4)$ \\
$0.26-0.50$ & $450(12.1)$ & $545(14.7)$ & $490(13.2)$ & $563(15.2)$ \\
$0.51-0.75$ & $707(19.1)$ & $714(19.3)$ & $812(21.9)$ & $969(26.2)$ \\
$>0.76$ & $863(23.3)$ & $878(23.7)$ & $1028(27.8)$ & $1341(36.2)$ \\
\hline
\end{tabular}


En las curvas típicas modeladas con la función de Wood para valores que se incrementan de $b$, existe una tasa de incremento de las estimaciones en la primera parte de la lactancia (Figura 1a), mientras que en las curvas atípicas (Figura 1b) los incrementos de b resultan en una reducida persistencia. En cambio, en las contrast, the typical curves had a convex shape that was accentuated by negative $b$ values (Figure 1c), whereas in atypical curves positive b values accentuated the curve's concave shape (Figure 1d). This highlights the difference in meaning of the $b$ parameter between the two curve groups within the same model, and

Cuadro 2. Medias y desviaciones estándar de los parámetros para curvas individuales, clasificados de acuerdo con las cuatro formas detectadas por los modelos de Wood y de Wilmink

Table 2. Means and standard deviations of individual curve parameters classified according to the four shapes identified by the Wood and Wilmink models

\begin{tabular}{|c|c|c|c|c|c|c|c|c|}
\hline \multirow[b]{2}{*}{ Shape§ } & \multicolumn{4}{|c|}{ Wood Model } & \multicolumn{3}{|c|}{ Wilmink Model } & \multirow[b]{2}{*}{$\log C$} \\
\hline & nI & $\log a$ & $\log b$ & $\log C$ & $\mathrm{n} \pi$ & $\log a$ & $\log b$ & \\
\hline 1 & 523 & $3.5 \pm 3.7$ & $0.64 \pm 0.6$ & $-0.01 \pm 0.01$ & 409 & $11.1 \pm 3.7$ & $-8.2 \pm 7.9$ & $-0.4 \pm 0$ \\
\hline 2 & 199 & $24.3 \pm 20.5$ & $-0.21 \pm 0.1$ & $-0.01 \pm 0.01$ & 380 & $7.8 \pm 3.2$ & $7.2 \pm 6.6$ & $-0.02 \pm 0$ \\
\hline 3 & 133 & $52.9 \pm 40.2$ & $-0.74 \pm 0.4$ & $0.01 \pm 0.01$ & 77 & $2.1 \pm 1.1$ & $13.9 \pm 11$ & $0.01 \pm 0$ \\
\hline 4 & 8 & $1.8 \pm 2.7$ & $0.28 \pm 0.1$ & $0.01 \pm 0.01$ & 12 & $4.7 \pm 3.1$ & $-5.0 \pm 6.2$ & $0.01 \pm 0$ \\
\hline
\end{tabular}

$\S$ Lactation curve shapes: $1=$ typical; $2=$ continuously descending (atypical); $3=$ reverse standard; $4=$ continuously increasing. T sample size.

Figura 1. Formas de curvas típicas (a y c) y atípicas (b y d) detectadas por los modelos de Wood y de Wilmink, seleccionadas para valores crecientes del parámetro $b$

Figure 1. Typical ( $a$ and $c$ ) and atypical ( $b$ and $d$ ) lactation curve shapes identified by the Wood and Wilmink models; chosen for increasing $b$ parameter values. DIM= days in milk; TDYM= test day yield milk

Wood

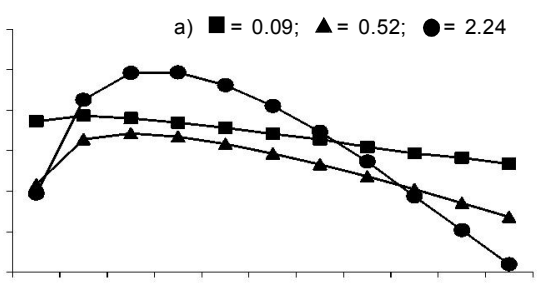

Wilmink

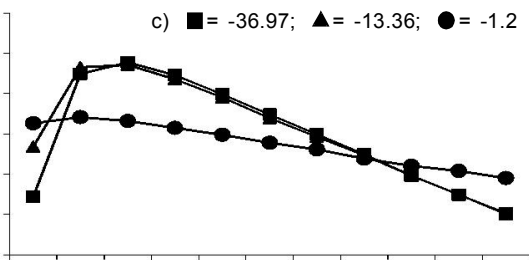

b) $\boldsymbol{\square}=-0.57 ; \boldsymbol{\Delta}=-0.200 ; \quad \boldsymbol{O}=-0.029$

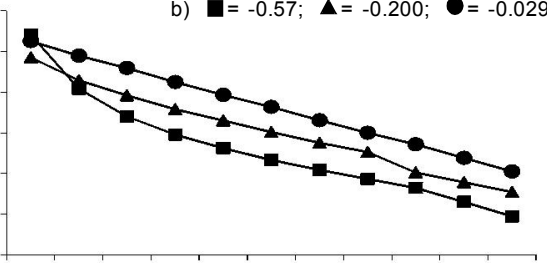

d) $\boldsymbol{\square}=0.09 ; \boldsymbol{\Delta}=8.39 ; \quad \boldsymbol{O}=16.7$

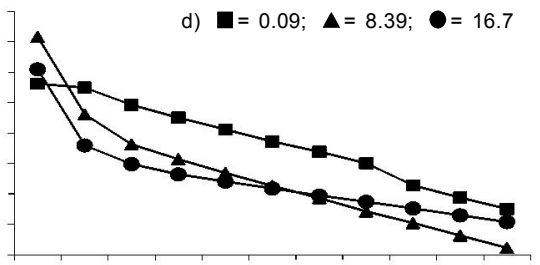


curvas típicas obtenidas con la función de Wilmink, la forma convexa se acentúa para valores negativos de $b$ (Figura 1c), mientras que en las atípicas, valores positivos de $b$ acentúan la forma cóncava de la curva (Figura 1d). Lo anterior resalta la diferencia en el significado del parámetro $b$ entre los dos grupos de curvas dentro del mismo modelo; confirmando además la relación entre los valores de $b$ y la tasa de variación en la primera parte de la curva.

Los modelos de Ali-Schaeffer y Legendre reconocieron 17 y 20 tipos de curvas, respectivamente, de los 32 grupos teóricos posibles. Sin embargo, cada grupo puede ser considerado el resultado de una deformación específica de las dos formas básicas (típica o atípica), presentándose cierta variabilidad en función de la presencia de puntos de inflexión en los distintos grupos de curvas. Se consideraron los cuatro grupos de curvas con mayor frecuencia. Las medias de los valores absolutos para los parámetros de las curvas obtenidas con Ali-Schaffer se presentan en el Cuadro 3.

Las curvas individuales estimadas para los cuatro grupos principales con el modelo de Ali Schaeffer se presentan en la Figura 2 . En el grupo 1 (Figura 2a) el incremento del parámetro b representa un aumento de la producción de leche al principio de la lactancia. En el grupo 2 (Figura $2 \mathrm{~b}$ ) un incremento en b enmarca la confirms the link between $b$ values and the variation rate in the first portion of the curve.

Of the 32 theoretically possible groups, the AliSchaeffer model identified 17 curve types and the Legendre polynomials model 20 types. Nonetheless, each group was essentially the result of a specific deformation of the two basic shapes (typical and atypical). Variability occurred in the form of inflexion points within the two curve groups. The four curve groups with the highest frequencies were included in the analysis (Table 3).

Estimates for individual curves were generated for each of the four main Ali-Schaeffer model curve groups (Figure 2). In group 1, the increase in parameter $b$ represented a rise in milk production at the beginning of lactation (Figure 2a), whereas in group 2 an increase in b marked the decline rate of the curve's initial portion. Inflexion points occurred in both groups at $60 \mathrm{~d}$, a clear consequence of the high flexibility of five-parameter models, which can identify different rates of decreased or increased milk production throughout lactation. However, the opposite sign in the parameters means that the sequence of changes in curvature is the opposite in the two groups. The patterns in groups 3 (Figure $2 \mathrm{c}$ ) and 4 (Figure $2 \mathrm{~d}$ ) are examples of different consequences in response to an increase in the b parameter. In group 3, the curvature in the second portion increased while in group 4 it tended to decline linearly.

Cuadro 3. Distribución de los parámetros (media \pm desviación estándar) de curvas individuales clasificadas de acuerdo con los cuatro grupos con mayor frecuencia detectados por Ali Schaeffer

Table 3. Parameter distribution (mean \pm standard deviation) of individual curves classified based on the four groups most frequently identified by the Ali-Schaeffer model

\begin{tabular}{lcrrrrr}
\hline Group & Frequency & \multicolumn{1}{c}{$\mathrm{a}$} & \multicolumn{1}{c}{$\mathrm{b}$} & \multicolumn{1}{c}{$\mathrm{c}$} & \multicolumn{1}{c}{$\mathrm{d}$} & \multicolumn{1}{c}{$\mathrm{e}$} \\
\hline 1 & 437 & $-180.2 \pm 25.1$ & $296.4 \pm 42.0$ & $-131 \pm 21.7$ & $113.7 \pm 15.8$ & $-19.1 \pm 25.2$ \\
2 & 387 & $186.0 \pm 30.3$ & $-290.0 \pm 50.9$ & $118 \pm 23.2$ & $-107.3 \pm 18.4$ & $18.1 \pm 31.0$ \\
3 & 51 & $-29.1 \pm 29.6$ & $8.8 \pm 12.1$ & $51.9 \pm 64.6$ & $29.4 \pm 28.2$ & $-5.9 \pm 6.8$ \\
4 & 42 & $4.2 \pm 3.5$ & $7.2 \pm 5.7$ & $-18.6 \pm 14.4$ & $3.3 \pm 1.8$ & $-0.7 \pm 0.4$ \\
\hline
\end{tabular}


Figura 2. Ejemplos de formas de curvas del grupo 1 (a), 2 (b), 3 (c) y 4 (d) detectados por el modelo de Ali Schaeffer seleccionadas para valores que se incrementan del parámetro $b$

Figure 2. Examples of curve groups 1(a), 2 (b), 3 (c) and 4 (d) identified using the Ali-Schaeffer model, and selected for increasing $b$ parameter values. DIM= days in milk; TDYM= Test day yield milk
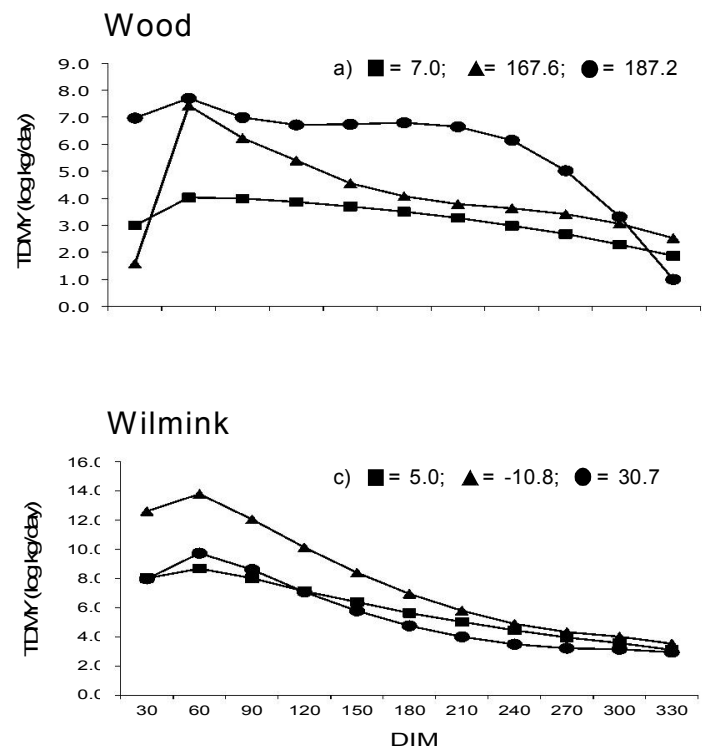

tasa de declive de la parte inicial de la curva. En ambos grupos se observan puntos de inflexión ubicados a los 60 días, una clara consecuencia de la alta flexibilidad de los modelos de cinco parámetros, que son capaces de reconocer las diferentes tasas de incremento o descenso en la producción de leche a través de la lactancia. Sin embargo, debido al signo opuesto de los parámetros, la secuencia de los cambios en la curvatura es opuesta en los dos
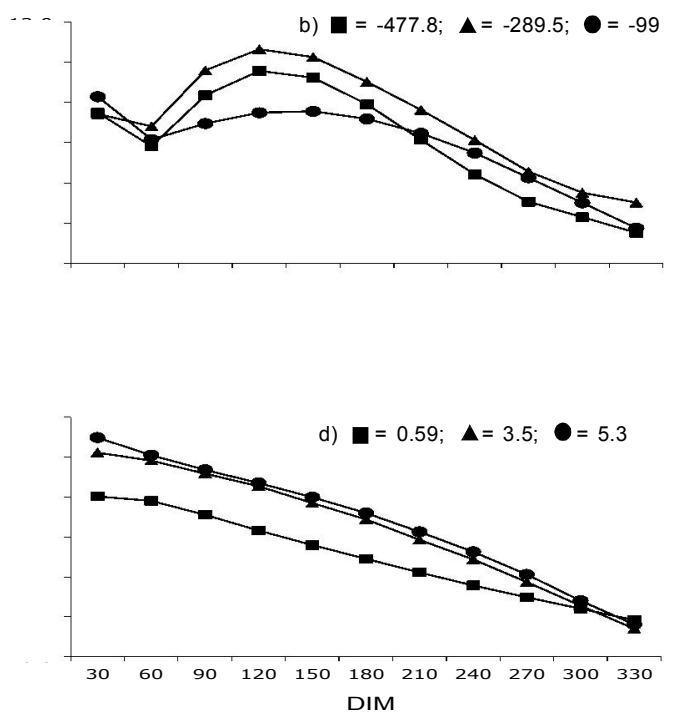

Among the four groups identified using Legendre polynomials (Table 4), a contrast in signs was present between groups 1 and 2, except for parameter $\alpha 0$, which was positive in both. Individual curves were generated for the four main groups for increasing values beginning from the term $\alpha 1$ (Figure 3). In group 1, increase in the $\alpha 1$ parameter caused a decrease in curve level and an increase in its curvature, while in group 2 an increase in $\alpha 1$ resulted in

Cuadro 4. Distribución de los parámetros (media \pm desviación estándar) de curvas individuales clasificadas de acuerdo con los cuatro principales grupos detectados por los polinomios ortogonales de Legendre

Table 4. Parameter distribution (mean \pm standard deviation) of individual curves classified based on the four main groups identified by Legendre orthogonal polynomials

\begin{tabular}{lcccccc}
\hline Group & Frequency & $\alpha 0$ & $\alpha 1$ & $\alpha 2$ & $\alpha 3$ & $\alpha 4$ \\
\hline 1 & 225 & $6.0 \pm 13.2$ & $7.2 \pm 17.8$ & $5.8 \pm 12.5$ & $2.8 \pm 5.3$ & $8.2 \pm 14.5$ \\
2 & 217 & $4.4 \pm 3.4$ & $-7.2 \pm 6.0$ & $-5.6 \pm 8.5$ & $-4.3 \pm 7.4$ & $-2.1 \pm 2.9$ \\
3 & 168 & $-8.6 \pm 13.6$ & $-1.2 \pm 17.4$ & $-8.8 \pm 12.2$ & $-41.3 \pm 55.0$ & $-10.9 \pm 12.8$ \\
4 & 113 & $7.4 \pm 3.7$ & $-2.6 \pm 2.1$ & $2.5 \pm 3.3$ & $2.2 \pm 3.3$ & $1.4 \pm 2.0$ \\
\hline
\end{tabular}


Figura 3. Ejemplos de formas de curvas de los grupos: 1 (a), 2 (b), 3 (c) y 4 (d) detectados por los polinomios ortogonales de Legendre seleccionadas para valores que se incrementan del parámetro $\alpha_{1}$

Figure 3. Examples of curve groups 1(a), 2 (b), 3 (c) and 4 (d) identified using Legendre orthogonal polynomials, and selected for increasing $\alpha_{1}$ parameter values. DIM= Days in milk; TDYM= Test day yield milk
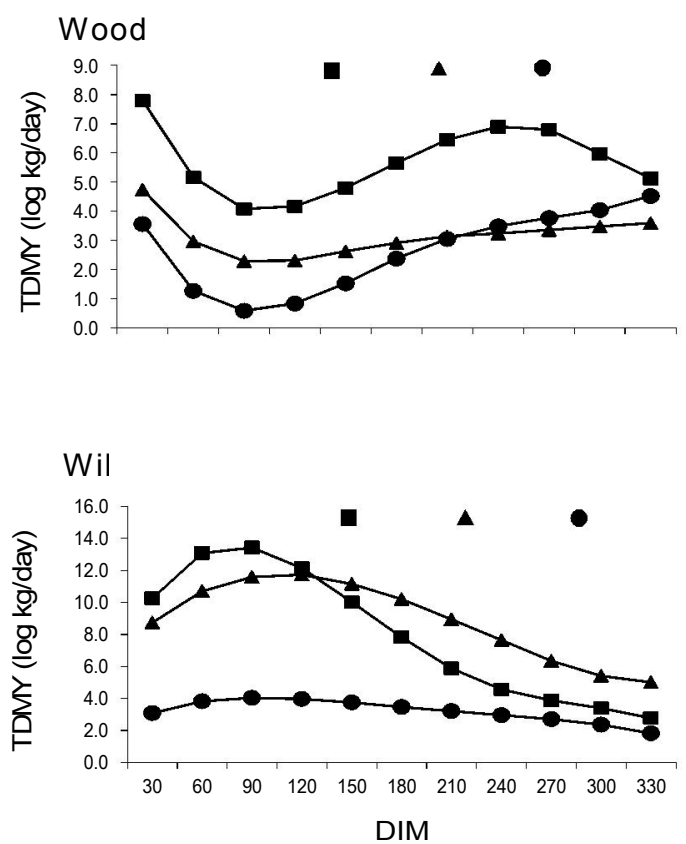

grupos. Los patrones extraídos de los grupos 3 y 4 (Figura 2c y Figura 2d, respectivamente) constituyen ejemplos donde el incremento del parámetro b tiene consecuencias diferentes. En el grupo 3, aumenta la curvatura en la segunda parte mientras que en el 4 muestra una tendencia lineal decreciente.

Los valores de los parámetros de los cuatro principales grupos de curvas detectadas con polinomios de Legendre se presentan en el Cuadro 4. Se observó un contraste de signos entre el grupo 1 y 2 , excepto para el parámetro $\alpha 0$ que fue positivo en ambos grupos.

La Figura 3 representa ejemplos de curvas individuales de los cuatro principales grupos, para valores que se incrementan del término $\alpha 1$. En el grupo 1, el incremento del parámetro $\alpha 1$ ocasiona un decremento del nivel de la curva


a lower slope and a more stable curve. The same behavior in response to increasing $\alpha 1$ values was also observed in groups 3 and 4 .

Of the correlations calculated between estimated parameters for the first two groups classified as typical and atypical curves with the Wood and Wilmink models, most were significant $(P<0.05)$. Of the correlations for the first two groups classified using the Ali-Schaeffer and Legendre polynomials models, significant $(P<0.05)$ correlations were found in all but group 2 of the Legendre curves (Table 5).

\section{DISCUSSION}

The TDMY values used in the present study were higher than those reported elsewhere for Siboney Cuba cattle $(27,28)$. In a study of 1,041 lactations in this genotype, $\mathrm{R}^{2} \mathrm{~A}$ values $>0.75$ 
y un aumento de la curvatura, mientras que en el grupo 2, produce menor pendiente y más estabilidad de la curva. Este comportamiento para los valores de $\alpha 1$ que se incrementan es evidente en los grupos 3 y 4 .

Las correlaciones entre los parámetros estimados $(P<0.05)$ para los dos primeros grupos clasificados como curvas típicas y atípicas para Wood y Wilmink y los dos primeros grupos para Ali-Schaeffer y Polinomios de Legendre de curvas y en los cuatro modelos estudiados se presentan en el Cuadro 5.

\section{DISCUSIÓN}

Los valores de PDC obtenidos en el presente trabajo fueron superiores a los encontrados en otros estudios en ganado Siboney de Cuba $(27,28)$. En un análisis de 1,041 lactancias de este genotipo, Fernández(27) determinó que were found in $21 \%$ of the lactations modeled with the Wood function and $39 \%$ of those modeled with the Ali-Schaeffer function(27).

Goodness of fit increased with the number of parameters included in the function since this is related to model flexibility $(21,29)$. However, the parameters used in polynomial functions do not necessarily have a clear relationship to the basic characteristics of lactation curve shape; this is particularly the case for high order polynomial functions(30). This makes biological interpretation difficult and leads to negative values at curve ends(13).

The a parameter value estimated here with the Wood function for the typical lactation curve was lower than that reported for Holstein cattle(31). This parameter's scale is directly related to milk production level. The lower value in the present study was expected since, in

Cuadro 5. Correlaciones estimadas entre los parámetros de los modelos analizados

Table 5. Correlations estimated between the parameters of the analyzed models

\begin{tabular}{|c|c|c|c|c|c|c|c|c|c|}
\hline & \multicolumn{9}{|c|}{ Three-parameter models } \\
\hline & \multirow[b]{2}{*}{ Parameter } & \multicolumn{2}{|c|}{ Standard } & & & & & Atypical & \\
\hline & & $\mathrm{b}$ & $\bar{c}$ & & & & & $\mathrm{~b}$ & c \\
\hline \multirow[t]{2}{*}{ Wood } & $a$ & -0.65 & 0.45 & & & & & -0.79 & $0.17^{*}$ \\
\hline & $b$ & & -0.83 & & & & & & -0.30 \\
\hline \multirow[t]{5}{*}{ Wilmink } & a & -0.23 & -0.71 & & & & & -0.03 & -0.74 \\
\hline & $b$ & & $0.11^{*}$ & & & & & & $0.17^{*}$ \\
\hline & & \multicolumn{8}{|c|}{ Five-parameter models } \\
\hline & & \multicolumn{4}{|c|}{ Group 1} & \multicolumn{4}{|c|}{ Group 2} \\
\hline & & $\mathrm{b} / \alpha 1$ & $\mathrm{c} / \alpha 2$ & $\mathrm{~d} / \alpha 3$ & $k / \alpha 4$ & $\mathrm{~b} / \alpha 1$ & $\mathrm{c} / \alpha 2$ & $\mathrm{~d} / \alpha 3$ & $\mathrm{k} / \alpha 4$ \\
\hline \multirow[t]{4}{*}{ Ali-Schaeffer } & a & -0.99 & 0.91 & -0.99 & 0.99 & -0.99 & 0.97 & -0.99 & 0.99 \\
\hline & b & & -0.98 & 0.99 & -0.97 & & -0.99 & 0.99 & -0.98 \\
\hline & c & & & -0.94 & 0.90 & & & -0.96 & 0.94 \\
\hline & $d$ & & & & -0.99 & & & & -0.99 \\
\hline \multirow[t]{4}{*}{ Legendre } & $\alpha 0$ & -0.27 & $-0.06^{*}$ & $0.18^{*}$ & $0.09^{*}$ & -0.81 & -0.53 & -0.73 & -0.31 \\
\hline & $\alpha 1$ & & $-0.13^{*}$ & 0.21 & $0.08^{*}$ & & -0.81 & -0.53 & -0.73 \\
\hline & $\alpha 2$ & & & $-0.20^{*}$ & $0.16^{*}$ & & & 0.49 & 0.47 \\
\hline & $\alpha 3$ & & & & 0.21 & & & & 0.58 \\
\hline
\end{tabular}

* Not significant values $(P>0.05)$. 
el 21 y $39 \%$ de las lactancias modeladas con la función de Wood y Ali-Schaeffer, respectivamente, presentaron $\mathrm{R}^{2} \mathrm{~A}$ superiores a 0.75 .

La bondad de ajuste se incrementa con el número de parámetros de la función, ya que está relacionada con la flexibilidad del modelo(21,29). Sin embargo, el uso de funciones polinomiales puede tener como inconveniente que los parámetros estimados usualmente no posean un significado claro en términos de relación con las características básicas de la forma de la curva de lactancia, especialmente las funciones polinomiales de órdenes elevados(30). Esto implica una interpretación biológica difícil y la presencia de valores negativos en los extremos(13).

El valor del parámetro a, estimado por la función de Wood para la forma típica de la curva de lactancia fue menor al reportado en estudios con ganado Holstein(31). La escala de este parámetro está relacionada directamente con el nivel de producción de leche. Este resultado era el esperado ya que el genotipo Siboney de Cuba, desde el punto de vista productivo responde a un programa de selección diseñado para una ganadería de bajos insumos en un clima tropical.

La característica distintiva de Wilmink con respecto a Wood es la independencia entre la primera y la segunda parte de la curva, confirmado por el valor inferior de correlación entre b y c, tanto para las curvas típicas como las atípicas. Macciotta et $a\left({ }^{22}\right)$ sugirieron que la dependencia entre parámetros puede ser la razón para la cantidad mayor de curvas estándar detectadas por el modelo de Wood, con respecto al de Wilmink.

Landete-Castillejos y Gallego(32) señalan diferencias en la habilidad de los modelos para describir formas de curvas de lactancia. De acuerdo con la segunda derivada de la función de Wood, el valor absoluto de b controla la magnitud de la curvatura del patrón de lactancia, terms of production traits, the selection program for the Siboney of Cuba genotype was designed to result in low input cattle for a tropical climate.

Compared to the Wood function, the outstanding element of the Wilmink function is the independence of the first and second portions of the curve. This is confirmed by the lower correlation value between $b$ and $c$ in both the typical and atypical curves. Macciotta et a(22) suggested that interparameter dependence may be the reason the Wood model identifies more standard curves than the Wilmink function.

These two models are known to differ in their ability to describe lactation curve shapes(32). According to the second derivative of the Wood function, the absolute value of $b$ controls lactation pattern curvature magnitude, which is the deviation of a straight line(24). In other words, when $b$ is positive the curve is concave and when it is negative the curve is convex.

Parameters generated with the Wood and Wilmink functions need to be analyzed with caution. A number of authors claim that the occurrence of peak less lactation curves is mainly due to results produced from records with no data for the first days of lactation. For example, the notable presence of negative $b$ parameter values refers to lactations with initial TDMY weighings at $30 \mathrm{~d}$ or more after parturition(24). However, atypical curves are apparently not strictly linked to the day the first TDMY record is made(33).

Peakless lactation curves have been described in dairy cattle(31), sheep(34), lambs(25), and buffaloes $(5)$. This may be a pattern characteristic of certain livestock breeds, including Siboney of Cuba, which has reported average lactation curves exhibiting a slightly flattened shape $(28,35)$.

High correlation between parameters in the AliSchaeffer model means a change in curvature with increases in $b$, and is a known limitation 
lo cual es la desviación de una línea recta(24), es decir, cuando $b$ es positivo la curva es cóncava y resulta convexa para valores negativos de $b$.

Los parámetros obtenidos a través de las funciones de Wood y Wilmink deben ser analizados con precaución. Varios autores sostienen que la ocurrencia de curvas sin pico de lactancia se debe a resultados obtenidos con la ausencia de registros en los primeros días de la lactancia, principalmente. Por ejemplo, en la función de Wood, una presencia relevante de valores negativos del parámetro $b$ ha sido referida para lactancias con los primeros pesajes de PDC a los 30 días o más, después del parto(24). Sin embargo, se ha planteado que las curvas atípicas no parecen estar estrictamente ligadas a los días en que se efectúa el primer registro de PDC(33).

Las curvas de lactancia sin pico se han descrito en ganado bovino de leche(31), ovejas(34), cabras (25) y búfalos(5). Algunos autores sugieren que puede ser un comportamiento característico de ciertas razas, y éste parece ser el caso del genotipo Siboney de Cuba, en el cual se han reportado curvas de lactancia promedios con un comportamiento ligeramente aplanado $(28,35)$.

La alta correlación entre los parámetros significa un cambio en la curvatura para el incremento del valor de $b$ y es una limitante conocida del modelo de Ali-Schaeffer(36), el cual puede enmascarar el proceso de estimación especialmente en análisis genéticos. Esta, entre otras razones, ha ocasionado el abandono del modelo de Ali-Schaeffer en favor de los polinomios de Legendre(23).

Al parecer, es común que se presente un efecto de borde en los grupos principales donde aparecen valores estimados negativos para las PDC en los extremos de la trayectoria de la lactancia(37). Este efecto de borde, característico de las curvas modeladas con Ali-Sheaeffer y polinomios de Legendre fue visualizado en el grupo 2. of this model since it can obscure the estimation process, particularly in genetic analyses. Among other reasons, this has led to abandonment of the Ali-Schaeffer model in favor of Legendre polynomials(23).

Apparently, an end effect is common in the main groups containing negative estimated TDMY values at the ends of the lactation trajectory(37). As seen in group 2, this edge effect is characteristic of curves modeled with the Ali-Schaeffer and Legendre polynomials functions.

Using the Legendre polynomials model, the correlations between estimated parameters were lower than with the Ali-Schaeffer model. Schaeffer(23) mentioned this behavior, and considered it difficult to identify the biological reasons explaining why the Ali-Schaeffer and Legendre polynomials functions can detect different types of curves. However, this behavior is particularly useful in random regression analyses searching for individual deviations in an average fixed curve.

\section{CONCLUSIONS AND IMPLICATIONS}

Using control day production data for Siboney dairy cows of Cuba, the four main mathematical functions used to predict milk production throughout lactation generated different lactation curve shapes, particularly in the five-parameter models. This shape diversity reflects curve diversity within the herd. Treating them as derivatives of the two classic typical and atypical curve groups could compromise variability among curves, since analyses based on average curves do not reflect the individuality of lactation behavior in a population. Use of three-parameter models as submodels in variance component estimations using control day production data should therefore be done with caution.

End of english version 
Las correlaciones entre los parámetros estimados por los Polinomios de Legendre fueron más bajas que las obtenidas para la función de AliSchaeffer. Este comportamiento fue referido por Schaeffer(23) quien considera difícil encontrar las razones biológicas por las cuales las funciones de Ali-Schaeffer y Polinomios de Legendre pueden detectar disímiles tipos de curvas, sin embargo, este comportamiento es particularmente útil para los análisis de regresión aleatoria, donde se buscan desviaciones individuales de una curva fija promedio.

\section{CONCLUSIONES E IMPLICACIONES}

De acuerdo con los resultados de este trabajo se concluye que las funciones matemáticas propuestas para describir la curva de producción de leche a lo largo de la lactancia representaron diferentes formas, en especial los modelos de cinco parámetros. Estas formas adicionales reflejan la diversidad de curvas dentro del hato, por lo que considerarlas derivaciones de los dos grupos clásicos de curvas típicas o atípicas podría comprometer la variabilidad entre curvas. Por lo tanto, los análisis basados en curvas promedios no reflejan la individualidad del comportamiento en la población. Esto sugiere que el uso de modelos de tres parámetros como submodelos en estimaciones de componentes de varianza usando PDC debe ser efectuado con cautela.

\section{LITERATURA CITADA}

1. Vinay-Vadillo JC, Villagómez-Cortés JA, Acosta-Rodríguez MR, Rocher C. Shapes of lactation curves of F1 (Holstein $X$ Zebu) cows in the humid tropic of Veracruz, México. Int J Anim Veter Adv 2012;4(6):370-377.

2. Jeretina J, Babnik D, Škorjanc D. Modeling lactation curve standards for test-day milk yield in Holstein, Brown Swiss and Simmental cows. J Anim Plant Sci 2013;23(3):754762.

3. Osorio MM, Segura JC. Factors affecting the lactation curve of dual purpose Bos taurus $x$ Bos indicus cows in the humid tropics of Tabasco, Mexico. Tec Pecu Mex 2005;43(1):127137.

4. Dijkstra J, López S, Bannink A, Dhanoa MS, Kebreab E, Odongo $\mathrm{NE}$, et al. Evaluation of a mechanistic lactation model using cow, goat and sheep data. J Agric Sci 2010;(148):249-262.

5. Macciotta NPP, Dimauro C, Catillo G, Coletta A, CappioBorlino A. Factors affecting individual lactation curve shape in Italian river buffaloes. Livest Sci 2006;104(1-2):33-37.

6. Cole J, Null D, VanRaden P. Best prediction of yields for long lactations. J Dairy Sci 2009;92(4):1796-1810.

7. Leclerc $H$, Duclos $D$, Barbat $A$, Druet $T$, Ducrocq V. Environmental effects on lactation curves included in a testday model genetic evaluation. Animal 2008;(2):344-353.

8. Bebbington $M$, Lai CD, Zitikis R. Modeling lactation curves: classical parametric models re-examined and modified. J Appl Stat 2009;(2)36:121-133.

9. Andersen F, Østerås O, Reksen O, Toft N, Gröhn YT. Associations between the time of conception and the shape of the lactation curve in early lactation in Norwegian dairy cattle. Acta Vet Scand 2011;53(5):1-8.

10. Wood PDP. Algebraic model of lactation curve in cattle. Nature 1967;(216):164-165.

11. Pollott GE. A biological approach to lactation curve analysis for milk yield. J Dairy Sci 2000;83(11):2448-2458.

12. Silvestre AM, Martins AM, Santos VA, Ginja MM, Colaço JA. Lactation curves for milk, fat and protein in dairy cows: $A$ full approach. Livest Sci 2009;122(2-3):308-313.

13. Al Faro LE, Albuquerque LG. Comparação de alguns modelos matemáticos para o ajuste as curvas de lactação individuais de vacas da raça Carcacu. Arq Braz Med Vet Zootec 2000;54(3):295-302.

14. Macciotta NPP, Dimauro C, Rassu SPG, Steri R, Giuseppe P. The mathematical description of lactation curves in dairy cattle. Ital J Anim Sci 2011;10(e51):213-223.

15. Macciotta NPP, Miglior F, Cappio-Borlino A, Schaeffer LR. Fit of different functions to the individual deviations in random regression test day models for milk yield in dairy cattle. Ital J Anim Sci 2007;6(1):153-155.

16. Ramírez $R$, Núñez $R$, Ruíz $A$, Meraz MR. Comparison of equations to estimate lactation curves with different sampling strategies in Angus, Swiss and their crosses. Vet Mex 2004;35(3):187-201.

17. Hernández I, Milera M, Simón $L$, Hernández $D$, Iglesias J, Lamela $\mathrm{L}$ et al. Avances en las investigaciones en sistemas silvopastoriles en Cuba. En: Sánchez MD, Rosales M. editors. Agroforestería para la producción animal en Latinoamérica. Roma: FAO; 1998:47-59.

18. Wilmink JBM. Studies on test-day and lactation milk, fat and protein yield of dairy cows [doctoral thesis]. Landbouwuniversiteit, Wageningen, Netherlands; 1987.

19. Ali TE, Schaeffer LR. Accounting for covariances among test day milk yields in dairy cows. Can J Anim Sci 1987;67(3):637-644.

20. Kirkpatrick M, Lofsuold D, Bulmer M. Analysis of inheritance, selection and evolution of growth trajectories. Genetics 1990;122(4):979-993.

21. Silvestre AM, Petim-Batista F, Colaco J. The accuracy of seven mathematical functions in modeling dairy cattle lactation curves based on test-day records from varying sampling schemes. J Dairy Sci 2006;89(5):1813-1821.

22. Macciotta NPP, Vicario D, Cappio-Barlino A. Detection of different shapes of lactation curve for milk yields in dairy 
cattle by empirical mathematical models. J Dairy Sci 2005;88(3):1178-1191.

23. Schaeffer LR. Application of random regression models in animal breeding. Livest Prod Sci 2004;86(1):35-45.

24. Congleton WR, Everett RW. Error and bias of the incomplete gamma function to describe lactation curves. J Dairy Sci 1980;63(1):101-108.

25. Macciotta NPP, Dimauro C, Steri R, Cappio-Borlino A. Mathematical modelling of goat lactation curves. In: Cannas A, Paulina G. editor. Dairy goats feeding and nutrition. 1rst ed. UK: CAB International; 2008:31-46.

26. SAS. SAS/STAT User's Guide (Release 6.08). Cary NC, USA: SAS Inst. Inc. 1995.

27. Fernández L, Menéndez A, Guerra D. Estudio comparativo de diferentes funciones para el análisis de la curva de lactancia en el genotipo Siboney de Cuba. Rev Cub Cien Agríc 2004;38(4):23-27.

28. González-Peña D. Evaluación genética del ganado Siboney de Cuba empleando la producción del día de control bajo un modelo de regresión aleatoria [tesis doctorado]. La Habana, Cuba: Universidad Agraria de La Habana; 2006.

29. Steri R. The mathematical description of the lactation curve of ruminants: issues and perspectives [doctoral thesis]. Sassari, Italia: Università di Sassari; 2009.

30. Cappio-Borlino A, Macciotta NPP, Pulina GG. Mathematical modelling of milk production patterns in dairy sheep. In:
Paulina G. editor. Dairy sheep nutrition. 1rst ed. UK: CAB International; 2004:13-29.

31. Rekik B, Ben-Gara A. Factors affecting the occurrence of atypical lactations for Holstein-Friesian cows. Livest Prod Sci 2004;87(2):240-245.

32. Landete-Castillejos T, Gallego L. Technical Note: The ability of mathematical models to describe the shape of lactation curves. J Anim Sci 2000;78(12):3010-3013.

33. Dimauro C, Vicario D, Canavesi F, Cappio-Borlino A, Macciotta NPP. Analysis of individual variability of the shape of lactation curve for milk fat and protein contents in Italian Simmental cows. Proc 8th World Cong Genetics Appl Livest Prod. Belo Horizonte, MG, Brasil. 2006.

34. Franci O, Pugliese C, Acciaioli A, Parisi G, Lucifero M. Application of two models to the lactation curve of Massese ewes. Small Ruminant Res 1999;31(2):91-96.

35. Hernández $R$, Ponce $P$. Caracterización de la curva de lactancia del genotipo Siboney de Cuba. Rev Cient (Maracaibo) 2008;18(3):291-295.

36. Kettunen A, Mäntysaari EA, Pösö J. Estimation of genetic parameters for milk yield of primiparous Ayrshire cow by random regression test day model. Livest Prod Sci 2000;66(3):251-261.

37. Pool MH, Meuwissen THE. Reduction of the number of parameters needed for a polynomials random regression test day model. Livest Prod Sci 2000;64(2-3):133-145. 